\title{
PENGARUH INTENSITAS CAHAYA TERHADAP KETERTARIKAN GEROMBOLAN IKAN PELAGIS KECIL PADA MINI PURSE SEINE DI PERAIRAN PEMALANG JAWA TENGAH
}

\author{
Erfind Nurdin'1), Mohammad Natsir ${ }^{1}$, dan Hufiadi1) \\ 1) Peneliti pada Balai Riset Perikanan Laut, Muara Baru-Jakarta
}

Teregristrasi I tanggal: 9 Desember 2005; Diterima setelah perbaikan tanggal: 12 April 2007; Disetujui terbit tanggal: 16 Juli 2007

\begin{abstract}
ABSTRAK
Penggunaan intensitas cahaya pada unit penangkapan light fishing cenderung meningkat. Hal ini, didasari atas persepsi bahwa intensitas cahaya yang tinggi akan meningkatkan hasil tangkapan. Fenomena ini dijadikan suatu penelitian yang dilakukan selama 3 minggu pada bulan September 2004 di perairan Pemalang Jawa Tengah. Alat tangkap pukat cincin mini (mini purse seine) di pantai utara Jawa pada operasi penangkapan selain menggunakan rumpon juga mengggunakan cahaya sebagai alat bantu penangkapan. Pengukuran nilai intensitas lampu dilakukan dengan meggunakan LI COR 250 quantum meter ( $\mu$ mol sÉ1 $\mathrm{mÉ}^{2}$ ) pada jumlah lampu yang berbeda, dan digunakan pula akustik EY 500 untuk memperoleh data sebaran dan gerombolan ikan yang berada dalam pengaruh cahaya lampu. Pada deteksi awal (A) ikan cenderung mengelompok pada lahan intensitas tinggi, deteksi ke-2 (B) pengelompokkan mulai terkonsentrasi dekat kapal, deteksi ke-3 (C) pengelompokkan ikan bertambah banyak, dan deteksi ke-4 (D) kelompok ikan berada pada lahan yang sangat memungkinkan untuk ditangkap. Dari hasil penelitian diperoleh laju tangkap (catch rate) $125,7 \mathrm{~kg}$ per tawur. Perbedaan jumlah lampu yang sedikit tidak menunjukkan pengaruh yang terlalu besar terhadap hasil tangkapan.
\end{abstract}

KATAKUNCl: $\quad$ pukat cincin mini, intensitas cahaya, pantai utara Jawa

ABSTRACT: The influence of light intensity for attracting of small pelagic shooling in north east of Java. By: Erfind Nurdin, Mohammad Natsir, and Hufiadi

The influence of light intensity to the light fishing practices commonly tends to increase. Fishermen believe that with the higher intensity of light the bigger catch they have. This phenomenon stimulated us to a research that during was done three weeks on September 2004 in Pemalang West Java. Mini purse seine is conduct at north coast of Java use payaos and light artificial for fish attractive. LI COR 250 quantum metre ( $\mu \mathrm{mol} s E^{1} \mathrm{mE}^{2}$ ) was used for light intencity at different lamps amount and EY 500 acoustic to obtain the data of fish school in influence of lamp light. At the first detecting $(A)$ fish school was concentrated in high intensity area, the second detecting $(B)$ the concentration was closer to the ship, the third detecting $(C)$ fish school increased, and the forth detecting $(D)$ fish school was consentrated in catchable area. The results show that the cath rate was $125.7 \mathrm{~kg}$ per setting. The difference of lamps amount with a small intensity did not show significant influence to the catch haul.

KEYWORDS: small purse seine, light intensity, north coast of Java

\section{PENDAHULUAN}

Di Indonesia armada penangkapan pukat cincin berkembang pesat sejak pelarangan operasi traw/ pada tahun 1980, mencapai puncak pada tahun 1985 dengan jumlah 520 unit. Ukuran kapal maupun alat tangkap terus bertambah besar dari tahun ke tahun, sehingga dapat menjangkau daerah penangkapan (fishing ground) yang semakin jauh (Wijopriono et al., 1995).

Alat bantu cahaya digunakan oleh nelayan pada unit penangkapan yang berbeda. Besar intensitas cahaya yang digunakan sangat tergantung pada jenis alat tangkap, target spesies, daerah penangkapan, dan kemampuan modal usaha. Pada perikanan pukat cincin alat bantu cahaya menggunakan sumber tenaga listrik generator dengan jenis lampu fluorescent yang berbeda sesuai dengan dimensi kapal (mini, medium, dan besar).

Alat bantu cahaya memiliki kecenderungan penggunaan intensitas cahaya yang semakin tinggi dalam operasi penangkapan berbagai alat tangkap. Saat ini, kompetisi di antara kapal-kapal pukat cincin dalam penggunaan cahaya semakin tinggi. Hasil penelitian di Laut Jawa menunjukkan bahwa beberapa kapal pukat cincin sudah menggunakan lampu fluorescent dengan kekuatan 30 Kw. (Sadhotomo \& Portier, 1995). Nelayan beranggapan bahwa semakin tinggi intensitas cahaya yang digunakan, semakin besar kelompok ikan yang dapat dikumpulkan. 


\section{BAHAN DAN METODE}

Penelitian dilakukan selama 3 minggu pada bulan September 2004 di perairan utara Jawa, Pemalang Jawa Tengah dengan megikuti proses penangkapan 3 unit kapal lampu purse seine dengan jumlah lampu yang berbeda 6, 7, dan 8 buah lampu (@400 watt), pengamatan hasil tangkapan untuk masing-masing unit kapal lampu dilakukan 9 kali ulangan.

Bahan yang digunakan adalah jaring purse seine yang terdiri atas 2 bagian utama yaitu sayap dan kantong dengan ukuran panjang $280 \mathrm{~m}$ dan dalam $13 \mathrm{~m}$. Kapal jaring secara garis besar terbuat dari bahan kayu dengan ukuran panjang $12 \mathrm{~m}$, lebar 3,5 m, dan dalam 1,2 m, bermesin diesel 24 HP. Kapal lampu terbuat dari kayu dengan panjang $10 \mathrm{~m}$, lebar 2,25 m, dan dalam $1 \mathrm{~m}$, bermesin diesel $16 \mathrm{HP}$.

Satu kapal jaring diikuti oleh 3 sampai dengan 4 kapal lampu. Dalam pengoperasiaan kapal jaring melakukan tawur setelah lampu dinyalakan selama 6 sampai dengan 7 jam, kemudian setelah semua pekerjaan selesai baru kapal jaring menuju kapal-kapal lampu untuk melakukan tawur secara bergantian.

Pengukuran kuat cahaya meggunakan quantum meter dengan satuan $\mu \mathrm{mol} s \hat{E}^{1} \mathrm{mÉ}^{2}$ pada intensitas atau jumlah lampu yang berbeda @400 watt meliputi 2 galaksi 5 merkuri (lampu I), 2 galaksi 6 merkuri (lampu II), dan 6 merkuri (lampu III). Pengukuran secara horisontal dilakukan dengan jarak setiap $2 \mathrm{~m}$ pada kedalaman $1 \mathrm{~m}$ di bawah permukaan air laut dan secara vertikal dengan jarak kedalaman setiap $1 \mathrm{~m}$ sampai dengan cahaya mendekati 0 terlihat pada quantum meter.

Data biologi diperoleh dengan cara identifikasi jenis (spesies), pengukuran terhadap panjang pangkal ekor (fork length) untuk ikan dominan dan menimbang bobot ikan hasil tangkapan serta bobot ikan per ekor untuk ikan dominan. Identifikasi jenis ikan hasil tangkapan dilakukan dengan mengacu pada buku FAO species identification sheet for fishery purposes (Fischer \& Whitehead, 1974).

Pengukuran kuat arus permukaan air laut menggunakan pelampung bola yang diikat pada seutas tali dan stop watch untuk mencatat lama waktu yang dibutuhkan. Untuk memperoleh data sebaran ikan yang berada dalam pengaruh cahaya lampu digunakan akustik EY 500 dengan menggunakan ping to ping analyse. Perekaman data akustik dilakukan berbasis pada posisi geografi (GPS), data jumlah sasaran disimpan secara simultan dengan data waktu dan posisi geografis kapal. Data ini yang kemudian diolah dengan cara ping to ping analisis, di mana setiap titik contoh data akan menghasilkan 1 unit data sasaran. Setelah dilakukan pengolahan file-file akustik yang telah diperoleh, dapat digambarkan sebaran sasaran hasil deteksi. Sebaran tersebut disajikan dalam bentuk kontur (Gambar 1).

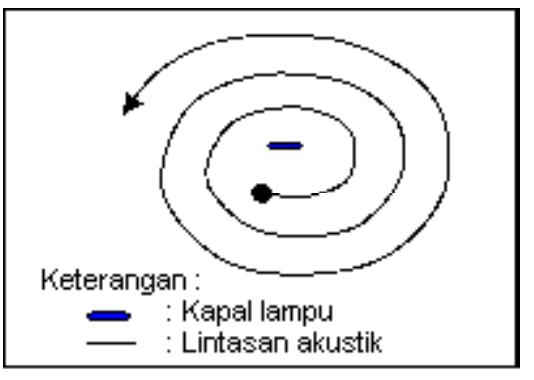

Gambar 1. Bentuk lintasan jalur pengambilan data akustik.

Figure 1. Track of acoustic data.

\section{HASIL DAN BAHASAN}

Secara umum, nelayan purse seine di Pemalang menggunakan 2 jenis armada kapal yaitu kapal jaring sebagai penangkap dan kapal lampu sebagai kapal bantu (3 sampai dengan 4 kapal lampu). Jaring purse seine di daerah ini terdiri atas 2 bagian utama yaitu sayap dan kantong. Bagian kantong terletak di tengah yang diapit bagian sayap pada ke-2 sisi dengan ukuran yang sama besar. Jaring berukuran panjang $280 \mathrm{~m}$ dan dalam $13 \mathrm{~m}$
(Lampiran 1). Kapal jaring secara garis besar, terbuat dari bahan kayu dengan ukuran panjang $12 \mathrm{~m}$, lebar 3,5 $\mathrm{m}$, dan dalam 1,2 $\mathrm{m}$ bermesin diesel $24 \mathrm{HP}$ dengan jumlah anak buah kapal mencapai 17 sampai dengan 20 orang. Kapal lampu terbuat dari kayu dengan panjang 10 $\mathrm{m}$, lebar 2,25 m, dan dalam $1 \mathrm{~m}$, dengan jumlah anak buah kapal 3 orang. Nelayan purse seine Pemalang melakukan aktivitas penangkapan tidak jauh dari basis, dengan jarak tempuh 10 sampai dengan 12 mil ( 3 sampai dengan 4 jam pelayaran). Daerah penangkapan berada 
di sekitar utara Tegal sampai dengan Pekalongan pada

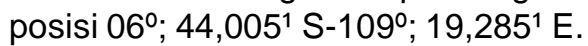

Penelitian dilakukan pada saat kuat arus permukaan air laut berbeda, pada lampu I kuat arus 7,4 m per menit, lampu II 24 m per menit, dan lampu III 6,6 m per menit. Intensitas sebaran cahaya di dalam air dipengaruhi oleh keadaan perairan seperti kecerahan, arus, dan gelombang dan terlihat sebaran cahaya pada ke-3 lampu tersebut secara umum memiliki pola yang sama (Gambar 2). Pada jarak $2 \mathrm{~m}$ dari sumber cahaya, secara vertikal di kedalaman $1 \mathrm{~m}$ intensitas cahaya pada perahu lampu I pada kisaran 0,33 $\mu \mathrm{mol}$ sÉ ${ }^{1} \mathrm{mÉ}^{2}$ dan mencapai titik nol pada kedalaman $27 \mathrm{~m}$. Intensitas cahaya pada lampu II pada jarak $3 \mathrm{~m}$ dari sumber cahaya di kedalaman $1 \mathrm{~m}$ berada pada kisaran $0,33 \mu \mathrm{mol} s E^{1} \mathrm{mÉ}^{2}$ dan mencapai titik nol pada kedalaman $15 \mathrm{~m}$, untuk lampu III intensitas cahaya pada jarak $3 \mathrm{~m}$ dari sumber cahaya di kedalaman $1 \mathrm{~m}$ berada pada kisaran 0,064 $\mu \mathrm{mol} \mathrm{sÉ}^{1} \mathrm{mÉ}^{2}$ dan mencapai titik nol pada kedalaman $16 \mathrm{~m}$.

Secara horisontal, sebaran cahaya dengan jarak 10 $\mathrm{m}$ dari pusat cahaya di perahu lampu I pada kedalaman $5 \mathrm{~m}$ secara efektif terdapat kuat cahaya sekitar 0,014 umol sÉ ${ }^{1} \mathrm{mÉ} 2$, lampu II dengan jarak $7 \mathrm{~m}$ dari pusat dan pada kedalaman $2 \mathrm{~m}$ secara efektif terdapat kuat cahaya $0,014 \mu \mathrm{mol} s E^{1} \mathrm{mÉ}^{2}$, lampu III dengan jarak $9 \mathrm{~m}$ dari pusat dan pada kedalaman $2 \mathrm{~m}$ terdapat kuat cahaya $0,014 \mu \mathrm{mol} s E^{1} \mathrm{mÉ} 2$.
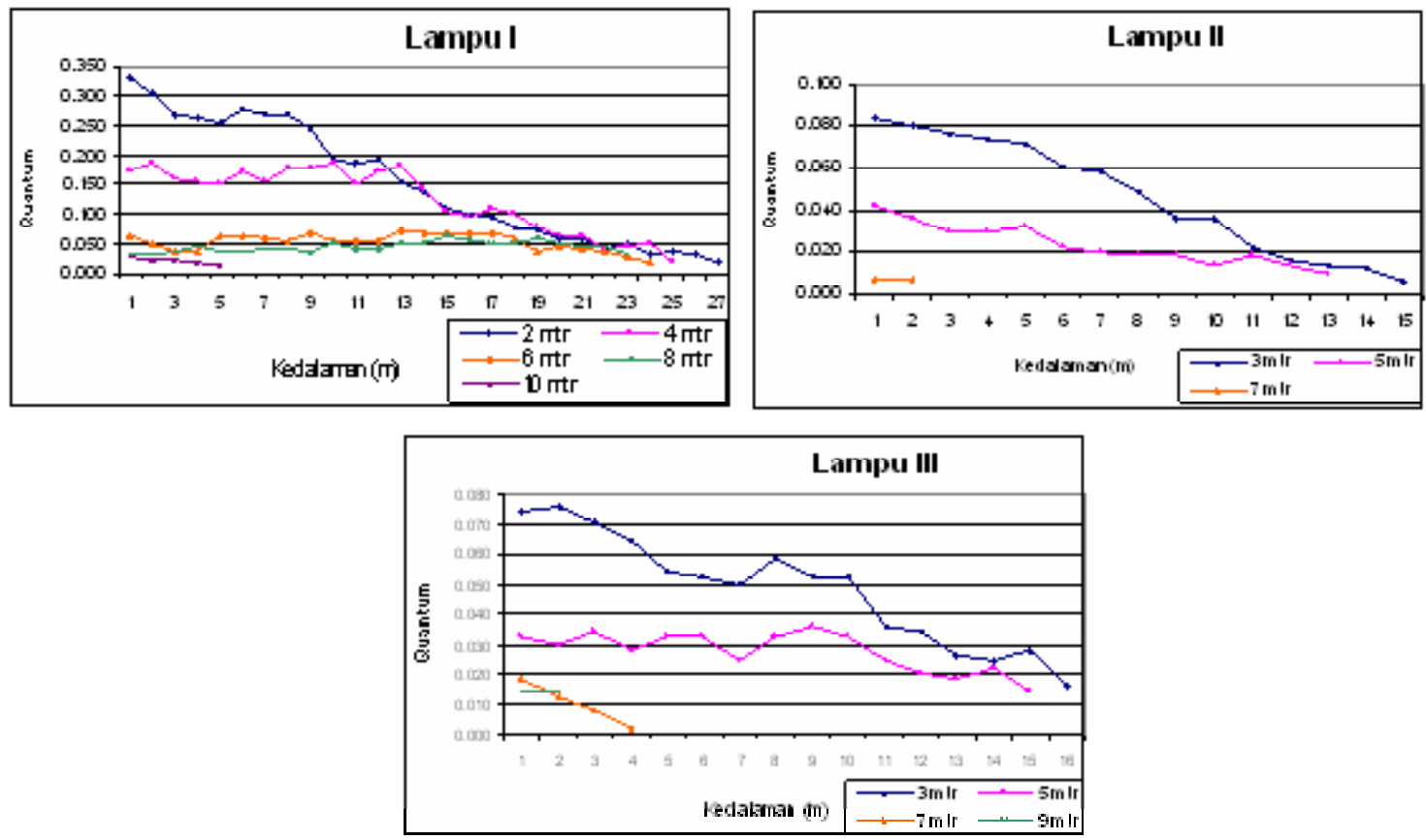

Gambar 2. Sebaran cahaya pada unit mini purse seine.

Figure 2. Light intencity of mini purse seine.

Pola pengelompokkan (agregasi) sasaran ikan dari ke-3 kapal (Lampiran 2, 3, dan 4) memiliki pola yang hampir sama. Pada deteksi awal (A) target cenderung mengelompok di area perairan dengan intensitas yang tinggi (terang). Pada area perairan dengan nilai intensitas lebih rendah (gelap) terdeteksi target dengan jumlah yang relatif lebih sedikit. Sebaran pada deteksi ke-2 (B) pengelompokkan sasaran mulai terkonsentrasi pada daerah yang lebih dekat dengan kapal. Pada fase ini mulai terdeteksi kelompok-kelompok ikan pada lahan yang memiliki jarak lebih jauh, kelompok ikan terdeteksi sampai dengan jarak $70 \mathrm{~m}$ dari pusat cahaya. Kelompok ikan pada deteksi ke-3 (C) menunjukkan pola yang hampir sama dengan bagian $B$, perbedaan yang nampak adalah semakin bertambah kelompok-kelompok sasaran yang memiliki jarak yang lebih jauh. Kelompok-kelompok ikan ini diperkirakan adalah ikan-ikan yang baru mendekat karena mulai tertarik akibat rangsangan cahaya (light attraction).

Pola agregasi pada deteksi ke-4 (D) menunjukkan peningkatan jumlah kelompok ikan. Kelompok ikan 
tersebut mulai mendekati sumber cahaya (kapal). Pada fase ini kelompok ikan berada pada lahan yang memungkinkan untuk ditangkap (catchable area). Berdasarkan pada pengamatan terdapat hubungan antara lama penyinaran dengan pola pengelompokkan ikan, terdapat kecenderungan semakin lama penyinaran semakin banyak konsentarsi sasaran yang terdeteksi.
Dari hasil pengamatan akustik yang dilakukan (Tabel 1) dengan melihat nilai target strength (db) menunjukkan bahwa perbedaan jumlah lampu dengan intensitas cahaya yang sedikit tidak mempengaruhi besar jumlah gerombolan ikan yang mendekati sumber cahaya. Gerombolan ikan yang terdeteksi didominasi oleh ikan berukuran kecil (-60 sampai dengan $-54 \mathrm{db}$ ).

Tabel 1. Distribusi ikan di bawah cahaya lampu untuk masing-masing nilai target strenght

Table 1. Fish distribution under light illumination in each target strength values

\begin{tabular}{|c|c|c|c|c|c|c|c|c|c|}
\hline \multirow{3}{*}{$\begin{array}{l}\text { Tipe lampu/ } \\
\text { Lamp type }\end{array}$} & \multirow{3}{*}{$\begin{array}{l}\text { Waktu/Time } \\
\text { (WIB) }\end{array}$} & \multicolumn{7}{|c|}{ Nilai target strength/Target strength value (db) } & \multirow{3}{*}{$\begin{array}{l}\text { Total } \\
\text { (ekor) }\end{array}$} \\
\hline & & -60 & -57 & -54 & -51 & -48 & -45 & -42 & \\
\hline & & \multicolumn{7}{|c|}{ Jumlah ikan (ekor) } & \\
\hline \multirow[t]{3}{*}{ Lampu I } & 21.52 & 468 & 401 & 88 & 45 & 5 & 0 & 0 & 1.007 \\
\hline & 23.12 & 376 & 180 & 35 & 15 & 5 & 0 & 1 & 612 \\
\hline & 02.20 & 426 & 502 & 142 & 79 & 7 & 0 & 1 & 1.157 \\
\hline \multirow[t]{3}{*}{ Lampu II } & 22.23 & 13 & 1 & 0 & 0 & 0 & 0 & 0 & 14 \\
\hline & 23.39 & 6 & 1 & 1 & 0 & 0 & 0 & 0 & 8 \\
\hline & 0.35 & 15 & 1 & 0 & 0 & 0 & 0 & 0 & 16 \\
\hline \multirow[t]{4}{*}{ Lampu III } & 19.28 & 31 & 14 & 1 & 2 & 0 & 0 & 0 & 48 \\
\hline & 21.04 & 24 & 5 & 1 & 1 & 0 & 0 & 0 & 31 \\
\hline & 21.35 & 24 & 4 & 2 & 0 & 0 & 0 & 0 & 30 \\
\hline & 22.07 & 16 & 6 & 0 & 1 & 1 & 0 & 0 & 24 \\
\hline
\end{tabular}

Sedangkan pengamatan konsentrasi gerombolan ikan yang dilakukan dengan melihat kedalaman perairan (Tabel 2) menunjukkan bahwa konsentrasi ikan pada tipe lampu I tersebar pada kedalaman 10 sampai dengan $30 \mathrm{~m}$, sedangkan tipe lampu II dan III konsentrasi gerombolan ikan pada kedalaman 20 sampai dengan $25 \mathrm{~m}$. Hal ini, mengindikasikan bahwa gerombolan ikan tersebar tidak merata pada setiap kedalaman.
Dari data perlakuan jumlah lampu dengan perbedaan intensitas cahaya yang relatif sedikit, terlihat bahwa jumlah ikan hasil tangkapan pada tiap ulangan operasi penangkapan tidak terlalu berbeda nyata. Hal ini, menandakan bahwa tidak selama kapal dengan jumlah lampu yang lebih banyak mendapatkan hasil tangkapan yang lebih banyak pula. Jumlah ikan hasil tangkapan untuk tiap ulangan dapat dilihat pada Tabel 3.

Tabel 2. Distribusi ikan di bawah cahaya lampu pada tiap kedalaman

Table 2. $\quad$ Fish distribution under light illumination in each target strength values

\begin{tabular}{|c|c|c|c|c|c|c|c|}
\hline \multirow{3}{*}{$\begin{array}{l}\text { Tipe lampu/ } \\
\text { Lamp type }\end{array}$} & \multirow{3}{*}{$\begin{array}{l}\text { Waktu/Time } \\
\text { (WIB) }\end{array}$} & \multicolumn{5}{|c|}{ Kedalaman/Depth $(\mathrm{m})$} & \multirow{3}{*}{$\begin{array}{c}\text { Total (ekor)/ } \\
\text { Total (ind.) }\end{array}$} \\
\hline & & $5-10$ & $10-15$ & $15-20$ & 20-25 & $25-30$ & \\
\hline & & \multicolumn{5}{|c|}{ Jumlah ikan(ekor)/Number of fish (ind.) } & \\
\hline \multirow[t]{3}{*}{ Lampu I } & 21.52 & 14 & 109 & 189 & 392 & 303 & 1.007 \\
\hline & 23.12 & 2 & 13 & 100 & 231 & 266 & 612 \\
\hline & 02.20 & 3 & 91 & 283 & 480 & 300 & 1.157 \\
\hline \multirow[t]{3}{*}{ Lampu II } & 22.23 & 0 & 0 & 2 & 12 & 0 & 14 \\
\hline & 23.39 & 0 & 1 & 0 & 7 & 0 & 8 \\
\hline & 0.35 & 0 & 0 & 1 & 15 & 0 & 16 \\
\hline \multirow[t]{4}{*}{ Lampu III } & 19.28 & 0 & 0 & 11 & 37 & 0 & 48 \\
\hline & 21.04 & 0 & 1 & 1 & 29 & 0 & 31 \\
\hline & 21.35 & 0 & 1 & 1 & 28 & 0 & 30 \\
\hline & 22.07 & 0 & 0 & 0 & 24 & 0 & 24 \\
\hline
\end{tabular}


Tabel 3. Data hasil tangkapan mini purse seine

Table 3. Data catch haul of mini purse seine by replication

\begin{tabular}{lcccccccccc}
\hline $\begin{array}{c}\text { Perlakuan } \\
\text { jumlah } \\
\text { lampu }\end{array}$ & \multicolumn{1}{c}{ Ulangan/Replication } & $\begin{array}{c}\text { Jumlah } \\
\text { (kg) }\end{array}$ \\
\cline { 2 - 12 } & $\mathbf{1}$ & $\mathbf{2}$ & $\mathbf{3}$ & $\mathbf{4}$ & $\mathbf{5}$ & $\mathbf{6}$ & $\mathbf{7}$ & $\mathbf{8}$ & $\mathbf{9}$ & \\
\hline Lampu I & 227 & 59,5 & 119,5 & 23 & 55 & 176 & 562 & 85 & 23 & 1.330 \\
Lampu II & 100 & 57 & 56 & 48 & 117 & 158 & 96 & 93 & 638 & 1.363 \\
Lampu III & 182 & 54 & 105,5 & 75 & 50 & 80 & 77 & 9 & 68 & 700,5 \\
\hline Jumlah & 509 & 170.5 & 281 & 146 & 222 & 414 & 735 & 187 & 729 & $3.393,5$ \\
\hline
\end{tabular}

Hasil tangkapan keseluruhan dari 27 kali ulangan penurunan jaring $3.393,5 \mathrm{~kg}$ dengan catch rate $125,7 \mathrm{~kg}$ per tawur didominasi oleh ikan tembang $60,39 \%$, layur $11,26 \%$, dan cumi $8,81 \%$ (Tabel 4 ).

Pengambilan contoh dilakukan terhadap 6 spesies ikan pelagis yang dominan, yaitu tetengkek (Megalaspis cordyla) 36 ekor, kembung (Restreliger brachyoma) 177 ekor, tembang (Sardinella fimbriata) 79 ekor, bentong (Selaroides boops) 30 ekor, selar kuning (Selaroides leptolepis) 144 ekor, dan bawal hitam (Formio niger) 48 ekor. Hasil pengukuran terhadap panjang cagak (FL) dan bobot (W) dapat dilihat pada Tabel 4.

Tabel 4. Persentase hasil tangkapan 27 ulangan, kisaran fork length, dan bobot ikan dominan tertangkap mini purse seine

Table 4. Percentage of haul in 27 restarting, length frequency, and weight of dominant fish

\begin{tabular}{clcccccc}
\hline No. & $\begin{array}{c}\text { Jenis/ } \\
\text { Species }\end{array}$ & $\begin{array}{c}\text { Jumlah/ } \\
\text { Number } \\
\text { (kg) }\end{array}$ & $\begin{array}{c}\text { Persentase/ } \\
\text { Percentage } \\
(\%)\end{array}$ & $\begin{array}{c}\text { Kisaran FL/ } \\
\text { Range } F L \\
\text { (cm) }\end{array}$ & $\begin{array}{c}\text { Rata-rata FL/ } \\
\text { Average of FL } \\
\text { (cm) }\end{array}$ & $\begin{array}{c}\text { Kisaran bobot// } \\
\text { Weight range } \\
\text { (g) }\end{array}$ & $\begin{array}{c}\text { Rata-rata bobot/ } \\
\text { Weight average } \\
\text { (g) }\end{array}$ \\
\hline 1. & Kembung & 91,5 & 2,70 & $8-9$ & 10,68 & $10-25$ & 15 \\
2. & Tetengkek & 73 & 2,15 & $16-26$ & 20,44 & $10-20$ & 14 \\
3. & Tembang & $2.049,5$ & 60,39 & $9-11$ & 9,62 & $13-17$ & 15 \\
4. & Bentong & 25,5 & 0,75 & $17-24$ & 19,87 & $14-40$ & 19 \\
5. & Selar & 80 & 2,36 & $10-20$ & 12,42 & $10-45$ & 29 \\
6. & Bawal & 103 & 3,04 & $18-28$ & 21,17 & $165-670$ & 325 \\
7. & Layur & 382 & 11,26 & & & & \\
8. & Cumi & 299 & 8,81 & & & & \\
9. & Tongkol & 228 & 6,72 & & & & \\
10. & Lain-lain & 62 & 1,83 & & & & \\
\hline
\end{tabular}

\section{KESIMPULAN}

1. Konsentrasi ikan target dipengaruhi oleh lama penyinaran, terdapat kecenderungan semakin lama penyinaran semakin tampak konsentrasi ikan target terdeteksi.

2. Penggunaan jumlah lampu tidak berpengaruh nyata terhadap hasil tangkapan.

\section{PERSANTUNAN}

Kegiatan dari hasil riset kinerja alat tangkap ikan pelagis dengan alat bantu cahaya ramah lingkungan di perairan pantai dan lepas pantai, T.A. 2004-2005, di Balai Riset Perikanan Laut, Muara Baru-Jakarta.

\section{DAFTAR PUSTAKA}

Fischer, W. \& P. J. P. Whitehead. 1974. Species identification sheet for fishery purposes. FAO.

Sadhotomo, B. \& M. Potier. 1995. Exploratory scheme for the recruitment and migration of the main pelagic species. Biodynex. Pelfis Project-CRIFI. p 155-168.

Wijopriono, J. Durant, \& P. Gueguen. 1995. Seiners vessels: Current status and potential innovation. Seminar on socio-economics, innovation, and management of the small pelagic fishery of the Java Sea. Bandungan Semarang. 4-7 December 1995. 
Lampiran 1. Desain mini purse seine Pemalang Appendix 1. Design of mini purse seine in Pemalang

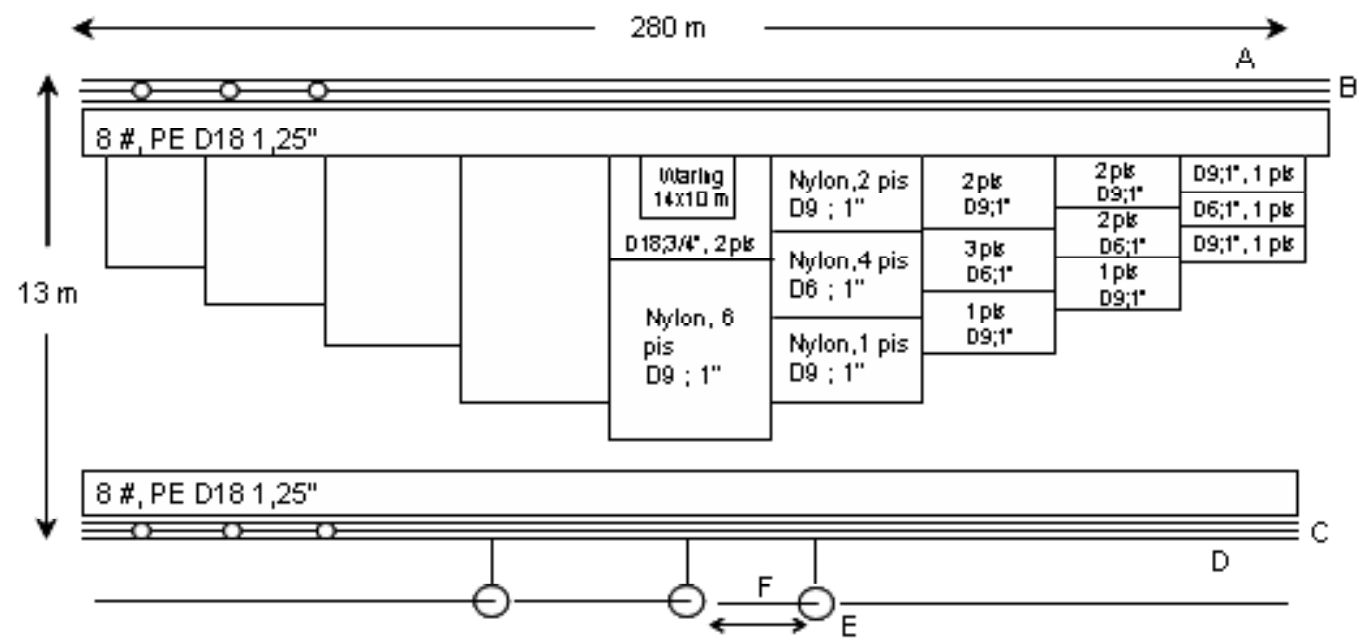

Keterangan/Remarks:

a. Tali ris atas PE $\varnothing 6 \mathrm{~mm}$.

b. Tali pelampung $280 \mathrm{~m}$, PE $\varnothing 6 \mathrm{~mm}$, Pelampung Y-50 (brown) dan A-8 (white).

c. Jarak antar pelampung $20-25 \mathrm{~cm}$.

d. Tali ris bawah PE $\varnothing 6 \mathrm{~mm}$

e. Tali pemberat $280 \mathrm{~m}, \mathrm{PE} \varnothing 10 \mathrm{~mm}$, Pemberat timah (@=125 g)

f. Jarak antar pemberat $20 \mathrm{~cm}$.

g. Cincin Kuningan $\varnothing 15 \mathrm{~cm}$, Tali kolor $350 \mathrm{~m}, \mathrm{PE} \varnothing 25 \mathrm{~mm}$.

h. Jarak antar cincin 3-4 m.

Lampiran 2. Sebaran sasaran pada kapal lampu I

Appendix 2. Pattern goal around $1^{\text {st }}$ lamp ship

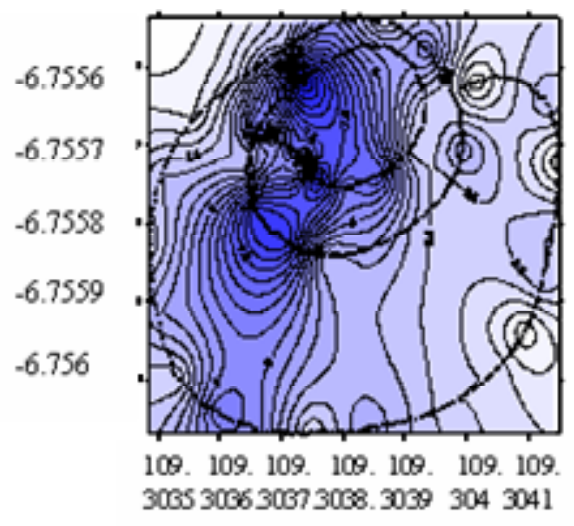

A. 21.52 WIB
$-6.3557$

$-6.7558$

$-6.7559$

$-6.756$

$-6.7561$

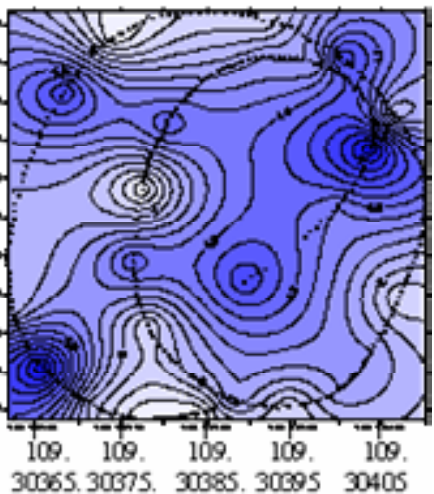

B. 23.12 WIB

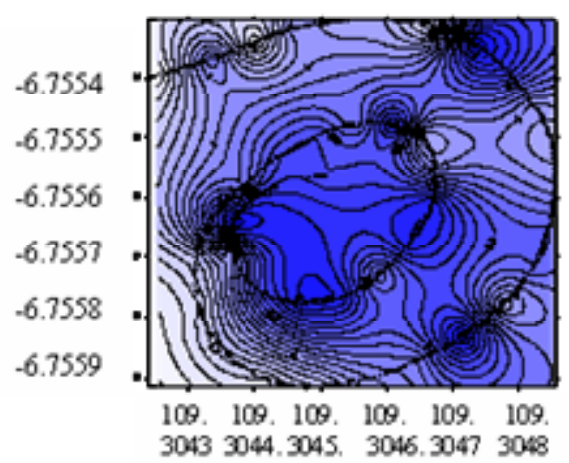

C.02.20 WIB

Keterangan/Remarks: Kapal menggunakan 7 lampu @400 watt yang terdiri atas 2 galaksi dan 5 merkuri 
Lampiran 3. Sebaran sasaran pada kapal lampu II Appendix 3. Pattern goal around $2^{\text {nd }}$ lamp ship
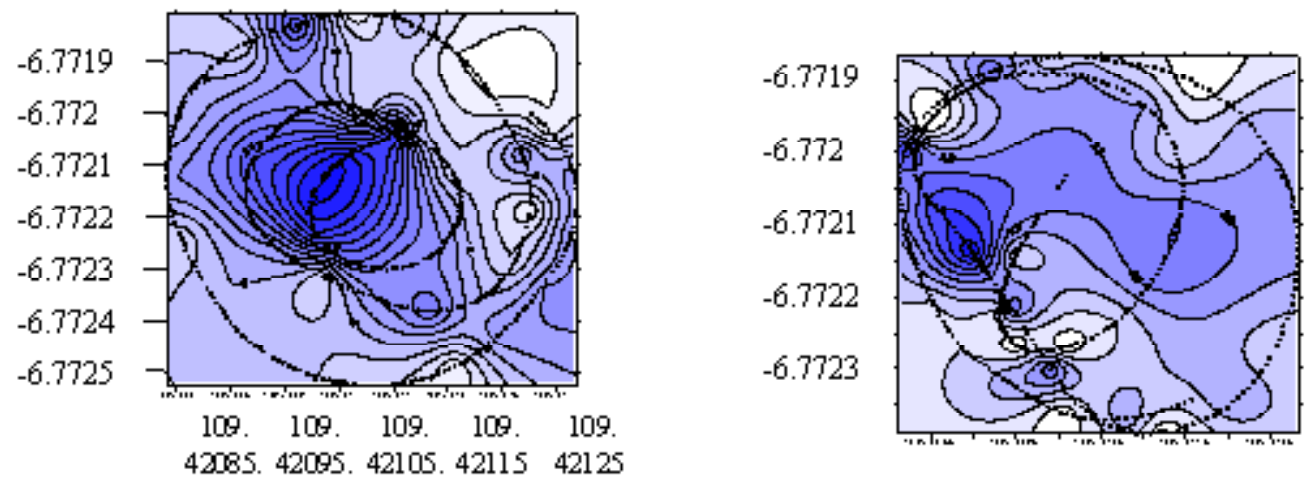

A. 22.23 WIB

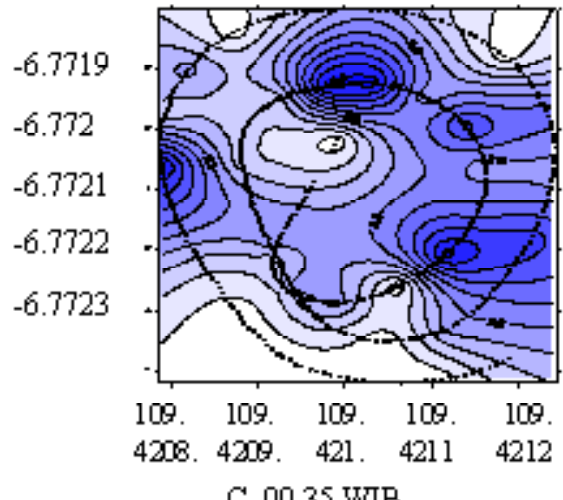

B. 23.39 WIB

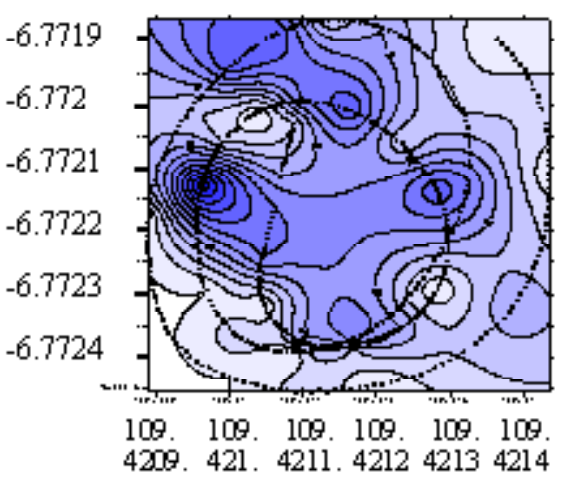

Keterangan/Remarks: Kapal menggunakan 8 lampu @400 watt yang terdiri atas 2 galaksi dan 6 merkuri 
Lampiran 4. Sebaran sasaran pada kapal lampu III Appendix 4. Pattern goal around $3^{\text {rd }}$ lamp ship

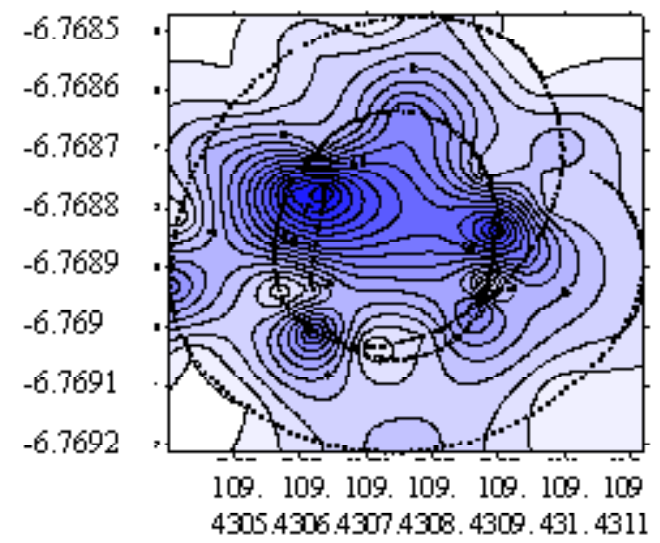

A. 19.28 WIB

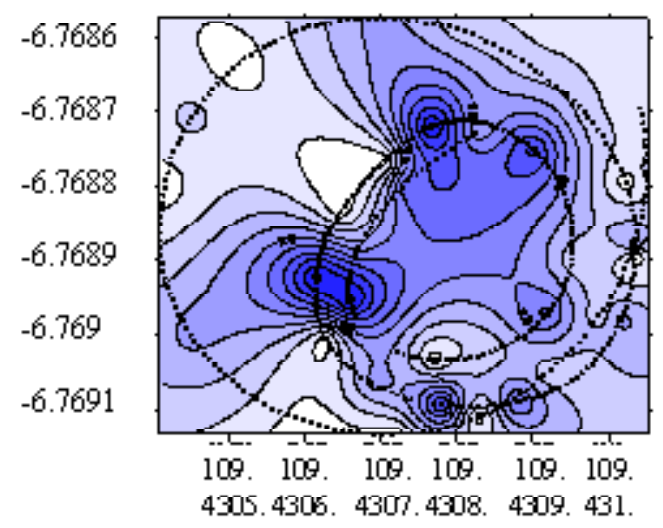

C. 21.35 WIB
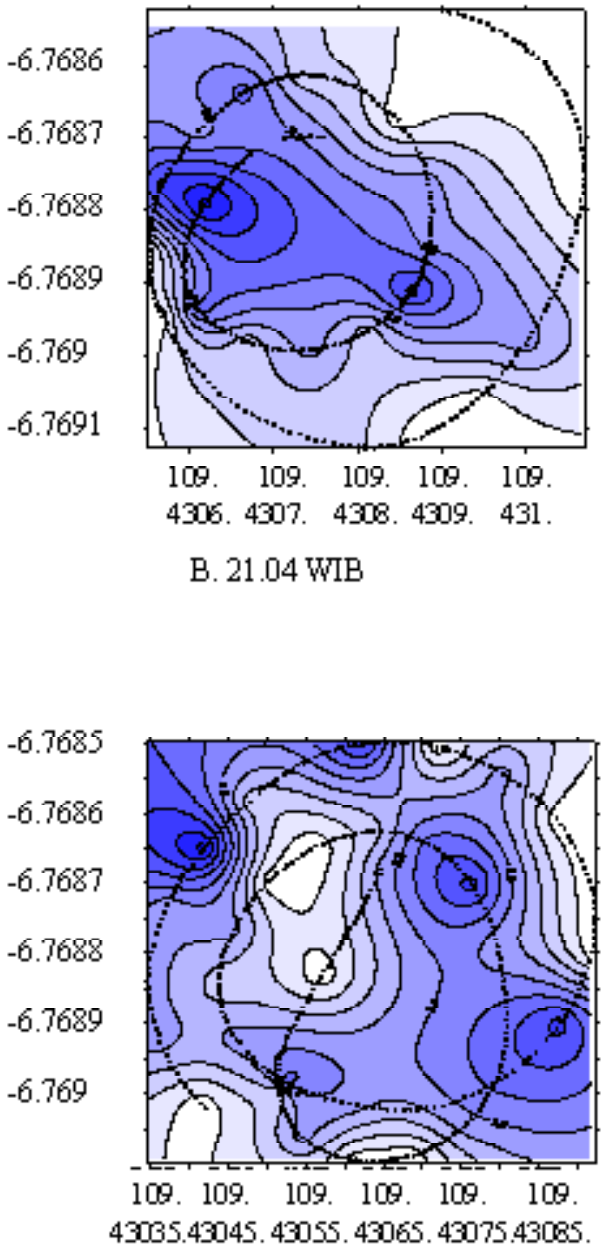

D. 22.07 WIB

Keterangan/Remarks: Kapal penangkap 6 lampu merkuri @400 Watt 